\title{
Diagnostic Yield and Safety of Cryoprobe Transbronchial Lung Biopsy in Diffuse Parenchymal Lung Diseases: Systematic Review and Meta-Analysis
}

\author{
Sahajal Dhooria MD DM, Inderpaul Singh Sehgal MD DM, Ashutosh N Aggarwal MD DM, \\ Digambar Behera MD, and Ritesh Agarwal MD DM
}

BACKGROUND: Transbronchial lung biopsy with flexible forceps is the most commonly used technique in diagnosis of diseases diffusely involving the lung parenchyma. Recently, transbronchial lung biopsy using the flexible cryoprobe (cryo-transbronchial lung biopsy) has also been reported. Herein, we perform a systematic review and meta-analysis describing the efficacy and safety of cryo-transbronchial lung biopsy. METHODS: The PubMed and EMBASE databases were searched for studies reporting the outcomes of cryo-transbronchial lung biopsy in subjects with diffuse parenchymal lung involvement. The quality of individual studies was assessed using the QualSyst tool. The pooled diagnostic yield of cryo-transbronchial lung biopsy was calculated using proportion meta-analysis (random effects model). Heterogeneity was evaluated using the $I^{2}$ test and Cochran $Q$ test. Publication bias was determined using both statistical and graphical methods. RESULTS: Our search yielded 14 studies (1,183 subjects). The pooled diagnostic yield of cryotransbronchial lung biopsy was $76.9 \%$ (95\% CI 67.2-85.3) if only definitive diagnoses were considered and $85.9 \%$ (95\% CI 78.2-92.2) if both definitive and probable diagnoses were considered. Four studies (321 subjects) the performance of flexible forceps biopsy and cryo-transbronchial lung biopsy. The diagnostic yield of cryo-transbronchial lung biopsy (86.3, 95\% CI 80.2-90.8) was significantly higher than that of flexible forceps biopsy $(56.5 \%, 95 \%$ CI $27.5-83.2)$ with an odds ratio of $6.7(95 \%$ CI 3.6-12.4) and a number needed to treat of 4 . Lung tissue was obtained in $98 \%$ of all samples with cryo-transbronchial lung biopsy and was free of compression artifacts. The size of samples obtained with cryo-transbronchial lung biopsy was significantly bigger compared with flexible forceps biopsy $\left(20.4 \mathrm{vs} 4.3 \mathrm{~mm}^{2}, P=.005\right)$. The complications of cryo-transbronchial lung biopsy included pneumothorax $(6.8 \%)$, severe bleeding $(0.3 \%)$, and death $(0.1 \%)$. Clinical and statistical heterogeneity was present, and there was evidence of publication bias. CONCLUSIONS: Cryo-transbronchial lung biopsy is a relatively safe procedure with good diagnostic yield in diseases diffusely involving the lung parenchyma. Key words: cryotherapy; interstitial lung disease; idiopathic pulmonary fibrosis; idiopathic interstitial pneumonia; sarcoidosis; bronchoscopy. [Respir Care 2016;61(5):700-712. (C) 2016 Daedalus Enterprises]

\section{Introduction}

Diffuse parenchymal lung diseases are a heterogeneous group of disorders that affect the pulmonary parenchyma

\footnotetext{
The authors are affiliated with the Department of Pulmonary Medicine, Postgraduate Institute of Medical Education and Research, Chandigarh, India.
}

The authors have disclosed no conflicts of interest. and include sarcoidosis, connective tissue disease-associated interstitial lung diseases, occupational lung diseases, idiopathic interstitial pneumonias, and others. ${ }^{1,2}$ Certain

Correspondence: Ritesh Agarwal MD DM, Department of Pulmonary
Medicine, Postgraduate Institute of Medical Education and Research,
Sector-12, Chandigarh 160012, India. E-mail: agarwal.ritesh@outlook.in.

DOI: $10.4187 /$ respcare. 04488 
infections, such as cytomegalovirus pneumonia, and post lung transplant conditions, such as acute rejection, diffusely involve the lung parenchyma and mimic other diffuse parenchymal lung diseases on radiologic evaluation. ${ }^{3,4}$

Transbronchial lung biopsy, performed with flexible forceps during flexible bronchoscopy, has been the most commonly employed technique for obtaining lung tissue for histopathological examination in diffuse parenchymal lung diseases. ${ }^{5,6}$ Flexible forceps biopsy is minimally invasive and does not require general anesthesia, thereby allowing the procedure to be performed on a day-care basis. ${ }^{7}$ However, it has significant limitations, including a variable diagnostic yield ranging from 30 to $75 \%$ (depending on the underlying disorders). It has an especially lower yield in fibrotic diffuse parenchymal lung diseases, such as idiopathic pulmonary fibrosis (IPF) and nonspecific interstitial pneumonia.6,8-10 Further, the size of the lung tissue specimen obtained with flexible forceps biopsy is small and frequently associated with artifacts (especially compression or crush artifacts), thus limiting its diagnostic utility. ${ }^{11,12}$ For this reason, flexible forceps biopsy is not recommended for the diagnosis of diffuse parenchymal lung diseases, such as IPF. ${ }^{13}$ Besides, the procedure is not without risk; pneumothorax and airway bleeding are important complications that might occur with flexible forceps biopsy and may result in hypoxia, ICU admissions, and prolonged hospital stay.7,14,15

Surgical lung biopsy provides large tissue samples for histopathological analysis and is the current reference standard for the diagnosis of idiopathic interstitial pneumonias, such as IPF, nonspecific interstitial pneumonia, and others. ${ }^{16}$ However, the procedure is performed in the operating room under general anesthesia and requires the mandatory insertion of an intercostal drain. It may be associated with significant morbidity (2-20\%), including prolonged air leak and prolonged hospital admission, and mortality $(2-17 \%){ }^{17-23}$

Transbronchial lung biopsy can also be performed using cryoprobes, termed cryo-transbronchial lung biopsy. ${ }^{24}$ Cryotherapy works on the principle of the Joule-Thomson effect, wherein the adiabatic expansion of a compressed gas leads to rapid cooling. The cooled tip of the cryoprobe adheres to the tissue due to crystallization of water molecules at the interface. Cryoprobes have been traditionally used during bronchoscopy for endobronchial tumor ablation, endobronchial biopsy, and recanalization by extraction of tumors and/or blood clots 25,26 ; their use for performing transbronchial lung biopsy is relatively recent. ${ }^{27}$ Herein, we perform a systematic review and meta-analysis of studies investigating the yield and safety of cryoprobe for performing cryo-transbronchial lung biopsy in subjects with disorders diffusely involving the lung parenchyma.

\section{QUICK LOOK}

\section{Current knowledge}

Transbronchial lung biopsy with flexible forceps and surgical lung biopsy are commonly used modalities in the diagnosis of diseases diffusely involving the lung parenchyma. Recently, transbronchial lung biopsy using the flexible cryoprobe (cryo-transbronchial lung biopsy) has also been reported.

\section{What this paper contributes to our knowledge}

The results of this study suggest that cryo-transbronchial lung biopsy has a good diagnostic yield in diseases diffusely involving the lung parenchyma with an acceptable safety profile.

\section{Methods}

\section{Search Strategy}

We first confirmed the absence of any systematic review in the PubMed and EMBASE databases on the role of cryo-transbronchial lung biopsy in diffuse lung diseases. Subsequently, all of the authors performed an independent search of the PubMed and EMBASE databases for relevant studies published through August 2015 describing the use of a cryoprobe for performing transbronchial lung biopsy in subjects with diseases diffusely involving the lung parenchyma. The following free text search terms were utilized: (cryo OR cryobiopsy OR cryobiopsies OR cryoprobe OR cryotherapy OR cryotechnology) AND (lung biopsy OR transbronchial OR trans-bronchial OR lung biopsies). The list of references of original, editorials, reviews, and our personal files were also checked for relevant citations. We excluded the following: (1) case reports, abstracts, comments, editorials, and reviews; (2) studies describing cryo-transbronchial lung biopsy in $<10$ subjects; (3) studies describing the use of cryo-transbronchial lung biopsy for a localized lung lesion; and (4) studies that could possibly have overlap of data with another study from the same center.

\section{Initial Review of Studies}

The bibliographic list thus retrieved from the electronic and manual searches was imported into the reference manager package, and all duplicate citations were discarded. Two authors (SD and RA) scrutinized these citations by examination of the title and abstract to identify the relevant studies. Any disagreement was resolved by discussion between the authors. This database was then screened 


\section{Cryoprobe Transbronchial Lung Biopsy in Diffuse Lung Diseases}

again to include only primary articles. The full text of each of these studies was obtained and reviewed in detail.

\section{Data Abstraction}

Data were entered into a standard data extraction form. The following items were extracted: (1) publication details (authors, year of publication, and other citation particulars, including the country of origin); (2) study design (prospective or retrospective); (3) patient population, number of subjects, and the comparator; (4) details of the procedure (anesthetic agents used and depth of anesthesia, use of rigid bronchoscopy or endotracheal intubation, the cryoprobe and cryogen used, duration of cooling, and duration of procedure); (5) characteristics of biopsy specimens (number, surface area, presence of lung tissue and alveolar spaces, presence of artifacts, and use of digital morphometry); (6) diagnostic characteristics (diagnostic yield, specific diagnoses, and diagnostic gold standard); and (7) complications associated with the procedure (severe bleeding defined according to British Thoracic Society guidelines, ${ }^{7}$ pneumothorax, and death). Complications were attributed to cryobiopsy for studies in which cryobiopsy and flexible forceps biopsy were performed in the same subject.

\section{Assessment of Study Quality}

Each study included in this review was adjudged for its quality and validity using the QualSyst tool for qualitative studies $^{28}$ independently by 2 authors (SD and RA) for the stated criteria. Weighted Cohen's kappa co-efficient was used to define the inter-observer agreement for selection of studies.

\section{Statistical Analysis}

The statistical software package StatsDirect 2.8.0 (StatsDirect Ltd, Altrincham, UK) was used to perform the statistical analyses. The diagnostic yield of cryo-transbronchial lung biopsy was analyzed by calculating the proportions for the individual studies $(n / N$, where $n$ is the number diagnosed with the help of cryo-transbronchial lung biopsy, and $N$ is the total number of subjects evaluated).29,30 The proportions were pooled using a DerSimonian random effects model in the presence of significant heterogeneity. The odds ratio and $95 \%$ CIs were calculated to assess the diagnostic yield in the cryo-transbronchial lung biopsy versus the flexible forceps biopsy group. The results from individual studies were pooled using the random effects model. ${ }^{31}$ The number needed to treat (equal to $1 /$ risk difference) was calculated to estimate the number of cryo-transbronchial lung biopsy procedures that need to be performed to achieve one additional diagnosis compared with flexible forceps biopsy.

\section{Assessment of Heterogeneity}

Heterogeneity for the individual outcomes was assessed using the $\mathrm{I}^{2}$ test, which measures the extent of inconsistency among the results of the studies. An $\mathrm{I}^{2}$ value of $\geq 50 \%$ indicates significant heterogeneity. ${ }^{32}$ Heterogeneity was also assessed using the Cochran Q statistic, and a $P$ value of $<.1$ was considered to be significant. ${ }^{33}$

\section{Estimation of Publication Bias}

The presence of publication bias was evaluated using the funnel plot (proportion on $\mathrm{x}$ axis against the standard error of the proportion on the $y$ axis). ${ }^{34}$ Publication bias was also investigated using the Egger test ${ }^{35}$ and Begg-Mazumdar test. ${ }^{36}$ An ethics committee approval was not required because this was a systematic review of published studies.

\section{Results}

The initial database search retrieved a total of 393 citations, of which 14 studies $(1,183$ subjects in total, 805 undergoing cryobiopsy) finally met the inclusion criteria (Fig. 1). ${ }^{27,37-49}$ Nine studies were retrospective, ${ }^{27,38-40,43,44,46-48}$ whereas 5 studies were prospective (4 observational, ${ }^{37,41,42,49}$ one randomized trial ${ }^{45}$ ) (Table 1). Ten studies were conducted in subjects with diffuse lung disease, $27,37,40,42-45,47-492$ in lung transplant recipients, ${ }^{39,41}$ one in immunocompromised subjects with pulmonary infiltrates, ${ }^{38}$ and one including subjects from all 3 categories ${ }^{46}$ (Table 1). The studies were generally of good quality (Table 2), with the median (interquartile range) QualSyst score being 18 (17-19). The inter-observer agreement for scoring of study quality was good (weighted Cohen's kappa $=70.3 \%$ ). Flexible forceps biopsy was the comparator in 6 studies, whereas cryobiopsy was compared against surgical lung biopsy in one study.

The procedures were performed most commonly under conscious sedation in spontaneously breathing subjects (11 studies); in one study, general anesthesia was employed, whereas in 2 other studies, either of the 2 modalities were used (Table 3). Midazolam with alfentanil (4 studies) and propofol with remifentanil (4 studies) were the most commonly used combinations of sedative/anesthetic and analgesic agents (Table 3). The subjects were intubated with one of the following artificial airways namely the endotracheal tube (6 studies), rigid bronchoscope (3 studies), or laryngeal mask airway (1 study). In 4 studies, the procedure was per- 


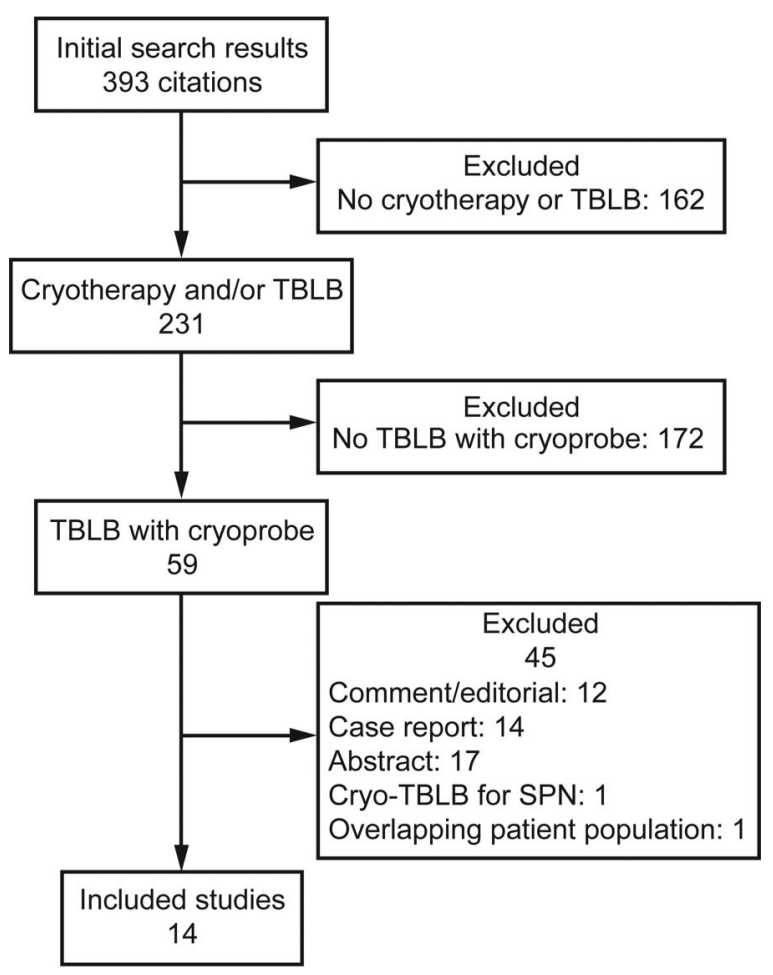

Fig. 1. Flow chart. TBLB = transbronchial lung biopsy; $\mathrm{SPN}=$ solitary pulmonary nodules.

formed without endotracheal intubation (Table 3). The procedures were performed through a flexible bronchoscope under fluoroscopic guidance in all of the studies. A 2.4-mm cryoprobe was used in a majority of the studies ( 9 studies), with nitrous oxide as the cryogen ( 8 studies) and a cooling time ranging from 3 to $6 \mathrm{~s}$ (Table $3)$. The mean duration of the procedure was reported in 6 studies and ranged from 6 to 35 min (Table 3). In most studies, $2-3$ cryobiopsy samples were obtained; in one study each, the number was 5 and up to 6 , respectively (Table 4). A chest radiograph was performed after the procedure in all of the studies. Digital morphometry was performed in 3 studies. ${ }^{27,43,44}$ The mean surface area of the biopsy samples was significantly higher with the cryoprobe in comparison with flexible forceps (20.4 vs $\left.4.3 \mathrm{~mm}^{2}, P=.005\right)$. Lung tissue was obtained in 391 of the $399(98 \%)$ cryobiopsy cases in which it was reported (Table 4). The number of alveolar spaces or percentage alveolated area as well as the artifact-free area was higher with the cryoprobe than with flexible forceps biopsy (Table 4). Artifacts associated with the use of the cryoprobe included cold-related artifacts, acute lung injury changes, and the presence of ciliated columnar epithelium in alveolar spaces. ${ }^{42,49}$ Nine studies explicitly defined a diagnostic reference standard (Table 5), which included: (1) interdisciplinary discussion between clinician, radiologist, and pathologist (5 studies); (2) clinical, radiographic, and pathological findings with 6-month follow-up (one study); and (3) clinical, radiographic, and pathological findings ( 3 studies).27,38,40,43-45,47-49 A variety of diffuse parenchymal lung diseases, including IPF and nonspecific interstitial pneumonia, could be diagnosed with the help of cryo-transbronchial lung biopsy (Table 5).

\section{Diagnostic Yield of Cryo-Transbronchial Lung Biopsy}

Twelve studies (472 subjects) reported the diagnostic yield of cryo-transbronchial lung biopsy (Table 5). ${ }^{27,37-40,42-45,47-49}$ Five studies further classified the diagnoses achieved with the help of cryo-transbronchial lung biopsy as definite (or confident) or probable. ${ }^{42,43,47-49}$ The diagnoses achieved in the remaining 7 studies were considered definite. $27,37-40,44,45$ The pooled diagnostic yield was 76.9\% (95\% CI 67.2-85.3) if only the definite diagnoses were considered, whereas it was $85.9 \%$ (95\% CI 78.2-92.2) when both definite and probable diagnoses were considered (Fig. 2). Four (3 observational, one randomized) studies (Table 6) compared the diagnostic yield of cryobiopsy (161 subjects) with flexible forceps biopsy (160 subjects). The diagnostic yield was significantly higher with cryotransbronchial lung biopsy $(86.3 \%$, 95\% CI 80.2-90.8\%) compared with flexible forceps biopsy $(56.5 \%, 95 \%$ CI $27.5-83.2 \%$ ) with an odds ratio of 6.7 (95\% CI 3.6-12.4\%), and a number needed to treat of 4 (Fig. 3).

\section{Safety of Cryo-Transbronchial Lung Biopsy}

Complications were reported by 13 studies for 764 cryotransbronchial lung biopsy procedures. Overall, there were 55 (7.2\%) major complications. Pneumothorax occurred in $52(6.8 \%)$, severe bleeding in $2(0.3 \%)$, and death in one $(0.1 \%)$ case (Table 7). The highest rate of pneumothorax (28\%) was observed in the study performed in subjects with fibrotic diffuse parenchymal lung diseases. ${ }^{42}$ The only death was also reported in the same study and was caused by an exacerbation of IPF. ${ }^{42}$

Clinical heterogeneity was evident in the nature of the studies (prospective vs retrospective), patient population, and diagnostic gold standards (Tables 1 and 5). Significant statistical heterogeneity was also observed for the outcome of diagnostic yield of the procedure $\left(\mathrm{I}^{2}=79.6\right.$; Cochran $\mathrm{Q}$ statistic 53.9, $P<.001)$. There was evidence of publication bias on visual examination of the funnel plot (Fig. 4) and on statistical tests (Begg-Mazumdar: Kendall's tau = $-0.545, P=.009$; Egger: bias $=-3.577, P<.001)$.

\section{Discussion}

The results of this study indicate that cryo-transbronchial lung biopsy has a good diagnostic yield (86\%), higher 
Table 1. Characteristics of the Included Studies

\begin{tabular}{|c|c|c|c|c|c|}
\hline Author (Year) & Country & Design & $\begin{array}{c}\text { Subjects, } N \\
\text { (Subjects Who Underwent } \\
\text { Cryo-TBLB, n) }\end{array}$ & Patient Population & Comparator \\
\hline Babiak et al (2009) ${ }^{27}$ & Germany & Retrospective & $41(41)$ & Diffuse lung disease on chest CT & FFB \\
\hline Pajares et al $(2010)^{37}$ & Spain & Prospective & $10(10)$ & Diffuse lung disease & None \\
\hline Fruchter et al $(2013)^{38}$ & Israel & Retrospective & $80(40)$ & $\begin{array}{l}\text { Lung transplant subjects undergoing } \\
\text { bronchoscopy (either surveillance or } \\
\text { clinically indicated) }\end{array}$ & FFB \\
\hline Fruchter et al $(2013)^{39}$ & Israel & Retrospective & $15(15)$ & $\begin{array}{l}\text { Immunocompromised subjects with } \\
\text { pulmonary infiltrates }\end{array}$ & None \\
\hline Kropski et al $(2013)^{40}$ & United States & Retrospective & $37(37)$ & $\begin{array}{l}\text { Suspected ILD with requirement of } \\
\text { lung biopsy, asymptomatic family } \\
\text { members at risk for FIP }\end{array}$ & None \\
\hline Yarmus et al $(2013)^{41}$ & United States & Prospective & $17(21)^{*}$ & $\begin{array}{l}\text { Bilateral lung transplant subjects } \\
\text { undergoing surveillance bronchoscopy }\end{array}$ & FFB \\
\hline Casoni et al $(2014)^{42}$ & Italy & Prospective & $73(69)$ & $\begin{array}{l}\text { Clinical and radiologic features of } \\
\text { fibrotic DPLD (insufficient to achieve } \\
\text { a specific diagnosis) }\end{array}$ & None \\
\hline Fruchter et al $(2014)^{43}$ & Israel & Retrospective & $75(75)$ & $\begin{array}{l}\text { Clinical, physiological and radiographic } \\
\text { features of undiagnosed ILD }\end{array}$ & None \\
\hline Griff et al $(2014)^{44}$ & Germany & Retrospective & $52(52)$ & $\begin{array}{l}\text { Diffuse interstitial non-neoplastic lung } \\
\text { diseases }\end{array}$ & None \\
\hline Pajares et al $(2014)^{45}$ & Spain & $\begin{array}{l}\text { Prospective, } \\
\text { randomized }\end{array}$ & $77(39)$ & Clinical and radiologic features of ILD & FFB \\
\hline Gershman et al $(2015)^{46}$ & Israel & Retrospective & $600(300)$ & $\begin{array}{l}\text { Immunocompromised subjects with } \\
\text { pulmonary infiltrates, lung transplant } \\
\text { subjects, subjects with diffuse } \\
\text { lung diseases }\end{array}$ & FFB \\
\hline Hagmeyer et al $(2015)^{47}$ & Germany & Retrospective & $32(32)$ & $\begin{array}{l}\text { Suspected ILD with equivocal diagnosis } \\
\text { on clinical features, serology, HRCT } \\
\text { and BAL }\end{array}$ & SLB \\
\hline $\begin{array}{l}\text { Hernández-González } \\
\text { et al }(2015)^{48}\end{array}$ & Spain & Retrospective & $33(33)$ & $\begin{array}{l}\text { ILD pattern on HRCT defined as } \\
\text { "possible UIP" or "inconsistent } \\
\text { with UIP" }\end{array}$ & None \\
\hline Pourabdollah et al (2015) ${ }^{49}$ & Iran & Prospective & $41(41)$ & Diffuse lung disease & FFB \\
\hline $\begin{array}{l}\text { * Twenty-one procedures were perfor } \\
\text { TBLB = transbronchial lung biopsy } \\
\text { CT }=\text { computed tomography } \\
\text { FFB = flexible forceps biopsy } \\
\text { ILD }=\text { interstitial lung disease } \\
\text { FIP }=\text { familial interstitial pneumonia } \\
\text { DPLD }=\text { diffuse parenchymal lung di } \\
\text { BAL }=\text { bronchoalveolar lavage } \\
\text { SLB }=\text { surgical lung biopsy } \\
\text { HRCT = high-resolution computed to } \\
\text { UIP }=\text { usual interstitial pneumonia }\end{array}$ & ed in 17 subjects. & & & & \\
\hline
\end{tabular}

than that of flexible forceps biopsy (57\%), for obtaining transbronchial lung biopsies in subjects who have diffuse parenchymal lung involvement. In fact, only 4 procedures need to be performed with cryo-transbronchial lung biopsy to obtain one additional diagnosis, compared with flexible forceps biopsy. The cryo-transbronchial lung biopsy procedure is generally safe, associated with a small risk of pneumothorax $(6.8 \%)$ and a very small risk of severe bleeding $(0.3 \%)$ and death $(0.1 \%)$.

The high yield of cryo-transbronchial lung biopsy can be attributed to several factors, including the presence of lung tissue in the biopsy specimen in almost all $(98 \%)$ cases, large size of the samples, and the absence of significant artifacts. When the cryoprobe is placed deep inside a sub-segmental bronchus and activated for 3-4 s, the lung parenchymal tissue freezes around the probe and adheres to the probe tip. Subsequent traction of the probe allows shearing off of a large volume of the lung parenchyma during withdrawal of the probe. This is unlike the flexible forceps biopsy technique, where the jaws of the forceps grasp the parenchyma, with the potential of causing compression/crush artifacts. The surface area of the 
Table 2. QualSyst Tool for Assessment of Quality of the Included Studies

\begin{tabular}{|c|c|c|c|c|c|c|c|c|c|c|c|c|c|c|}
\hline Criteria & $\begin{array}{l}\text { Babiak } \\
\text { et } \mathrm{al}^{27}\end{array}$ & $\begin{array}{l}\text { Pajares } \\
\text { et } \mathrm{al}^{37}\end{array}$ & $\begin{array}{l}\text { Fruchter } \\
\text { et } \mathrm{al}^{38}\end{array}$ & $\begin{array}{l}\text { Fruchter } \\
\text { et } \mathrm{al}^{39}\end{array}$ & $\begin{array}{l}\text { Kropski } \\
\text { et al }{ }^{40}\end{array}$ & $\begin{array}{l}\text { Yarmus } \\
\text { et } \mathrm{al}^{41}\end{array}$ & $\begin{array}{l}\text { Casoni } \mathrm{I} \\
\text { et } \mathrm{al}^{42}\end{array}$ & $\begin{array}{l}\text { Fruchter } \\
\text { et } \mathrm{al}^{43}\end{array}$ & $\begin{array}{l}\text { Griff } \\
\text { et } \mathrm{al}^{44}\end{array}$ & $\begin{array}{l}\text { Pajares } \\
\text { et } \mathrm{al}^{45}\end{array}$ & $\begin{array}{l}\text { Gershman } \\
\text { et } \mathrm{al}^{46}\end{array}$ & $\begin{array}{l}\text { Hagmeyer } \\
\text { et al }{ }^{47}\end{array}$ & $\begin{array}{l}\text { Hernández- } \\
\text { González } \\
\text { et al }{ }^{18}\end{array}$ & $\begin{array}{l}\text { Pourabdollah } \\
\text { et al }{ }^{49}\end{array}$ \\
\hline $\begin{array}{l}\text { 1. Question/objective } \\
\text { sufficiently described? }\end{array}$ & 2 & 2 & 2 & 2 & 2 & 2 & 2 & 2 & 2 & 2 & 2 & 2 & 2 & 2 \\
\hline $\begin{array}{l}\text { 2. Study design evident and } \\
\text { appropriate? }\end{array}$ & 1 & 2 & 1 & 1 & 1 & 2 & 2 & 1 & 2 & 2 & 2 & 1 & 1 & 2 \\
\hline $\begin{array}{l}\text { 3. Context for the study } \\
\text { clear? }\end{array}$ & 2 & 2 & 2 & 2 & 2 & 2 & 2 & 2 & 2 & 2 & 2 & 2 & 2 & 2 \\
\hline $\begin{array}{l}\text { 4. Connection to a } \\
\text { theoretical framework/ } \\
\text { wider body of } \\
\text { knowledge? }\end{array}$ & 2 & 2 & 2 & 2 & 2 & 2 & 2 & 2 & 2 & 2 & 2 & 2 & 2 & 2 \\
\hline $\begin{array}{l}\text { 5. Sampling strategy } \\
\text { described, relevant, and } \\
\text { justified? }\end{array}$ & 1 & 2 & 2 & 2 & 2 & 2 & 2 & 2 & 1 & 2 & 2 & 1 & 2 & 1 \\
\hline $\begin{array}{l}\text { 6. Data collection methods } \\
\text { clearly described and } \\
\text { systematic? }\end{array}$ & 1 & 2 & 1 & 2 & 2 & 2 & 2 & 1 & 2 & 2 & 2 & 2 & 2 & 2 \\
\hline $\begin{array}{l}\text { 7. Data analysis clearly } \\
\text { described and systematic? }\end{array}$ & 2 & 1 & 1 & 2 & 2 & 1 & 2 & 2 & 2 & 2 & 2 & 1 & 2 & 2 \\
\hline $\begin{array}{l}\text { 8. Use of verification } \\
\text { procedure(s) to establish } \\
\text { credibility? }\end{array}$ & 1 & 1 & 1 & 1 & 2 & 1 & 2 & 2 & 2 & 2 & 1 & 2 & 2 & 1 \\
\hline $\begin{array}{l}\text { 9. Conclusions supported by } \\
\text { the results? }\end{array}$ & 2 & 1 & 2 & 2 & 2 & 2 & 2 & 2 & 2 & 2 & 2 & 2 & 2 & 2 \\
\hline $\begin{array}{l}\text { 10. Reflexivity of the } \\
\text { account? }\end{array}$ & 2 & 2 & 2 & 2 & 2 & 2 & 2 & 1 & 2 & 2 & 1 & 2 & 2 & 2 \\
\hline Total & 16 & 17 & 16 & 18 & 19 & 18 & 20 & 17 & 19 & 20 & 18 & 17 & 19 & 18 \\
\hline
\end{tabular}

cryobiopsy specimen was higher than the flexible forceps biopsy samples by almost 5 times, and these larger samples with sufficient vascular and bronchiolar tissue help in a confident histological diagnosis of the subtype of the fibrotic diffuse parenchymal lung diseases as well as exclusion of cellular rejection and bronchiolitis in the lung transplant population. ${ }^{39}$

Although transbronchial flexible forceps biopsy provides a good diagnostic sensitivity in diseases like sarcoidosis, organizing pneumonia, lymphangitis carcinomatosis, and infections, the yield is poor in case of interstitial lung diseases, such as IPF, nonspecific interstitial pneumonia, respiratory bronchiolitis-associated interstitial lung disease, and others. ${ }^{9,10,50-52}$ This is due to the requirement of larger sized lung tissue for differentiating IPF from hypersensitivity pneumonitis and nonspecific interstitial pneumonia, as the former requires the demonstration of temporal and spatial heterogeneity. ${ }^{13}$ Further, other features like patchy interstitial fibrosis, fibroblast foci, and honeycombing need to be identified. ${ }^{13}$ A large variety of diffuse parenchymal lung diseases, which are difficult to be diagnosed confidently on small flexible forceps biopsy samples were diagnosed with cryo-transbronchial lung biopsy in the included studies (including IPF, nonspecific interstitial pneumonia, desquamative interstitial pneumonia, pulmonary Langerhans cell histiocytosis, and hypersensitivity pneumonitis), thus emphasizing the utility of this novel technique.
The present analysis also highlights the relative safety of the cryo-transbronchial lung biopsy procedure. The larger defect in the lung parenchyma resulting from a cryo-transbronchial lung biopsy is expected to increase the risk of pneumothorax significantly as compared with flexible forceps biopsy. The incidence of pneumothorax was $6.8 \%$ (52 of 764), which is higher than the usual reported rate reported with the flexible forceps biopsy.7,14,15,53,54 However, the risk of pneumothorax is less than that would be expected, considering the larger biopsy tissues obtained with cryo-transbronchial lung biopsy. The possible reasons include the universal use of fluoroscopy while performing cryo-transbronchial lung biopsy and fewer samples required for diagnosis with cryo-transbronchial lung biopsy. Moreover, one third of the pneumothoraces (19 of 52 ) in the present review occurred in a single study conducted in fibrotic diffuse parenchymal lung diseases. The authors of this study have attributed the high incidence (28\% in that study) to the type of patient population and the necessity to biopsy subpleural areas. Thus, the risk of pneumothorax with cryo-transbronchial lung biopsy is acceptable in most patients. Importantly, this needs to be interpreted in light of the fact that only a proportion of the patients (maximum 28\% ${ }^{42}$ would require an intercostal drain with cryo-transbronchial lung biopsy, compared with $100 \%$ patients who undergo surgical lung biopsy.

Severe bleeding (requiring either cessation of the procedure or the use of a bronchial blocker/sealant or surgical 
Cryoprobe Transbronchial Lung Biopsy in Diffuse Lung Diseases

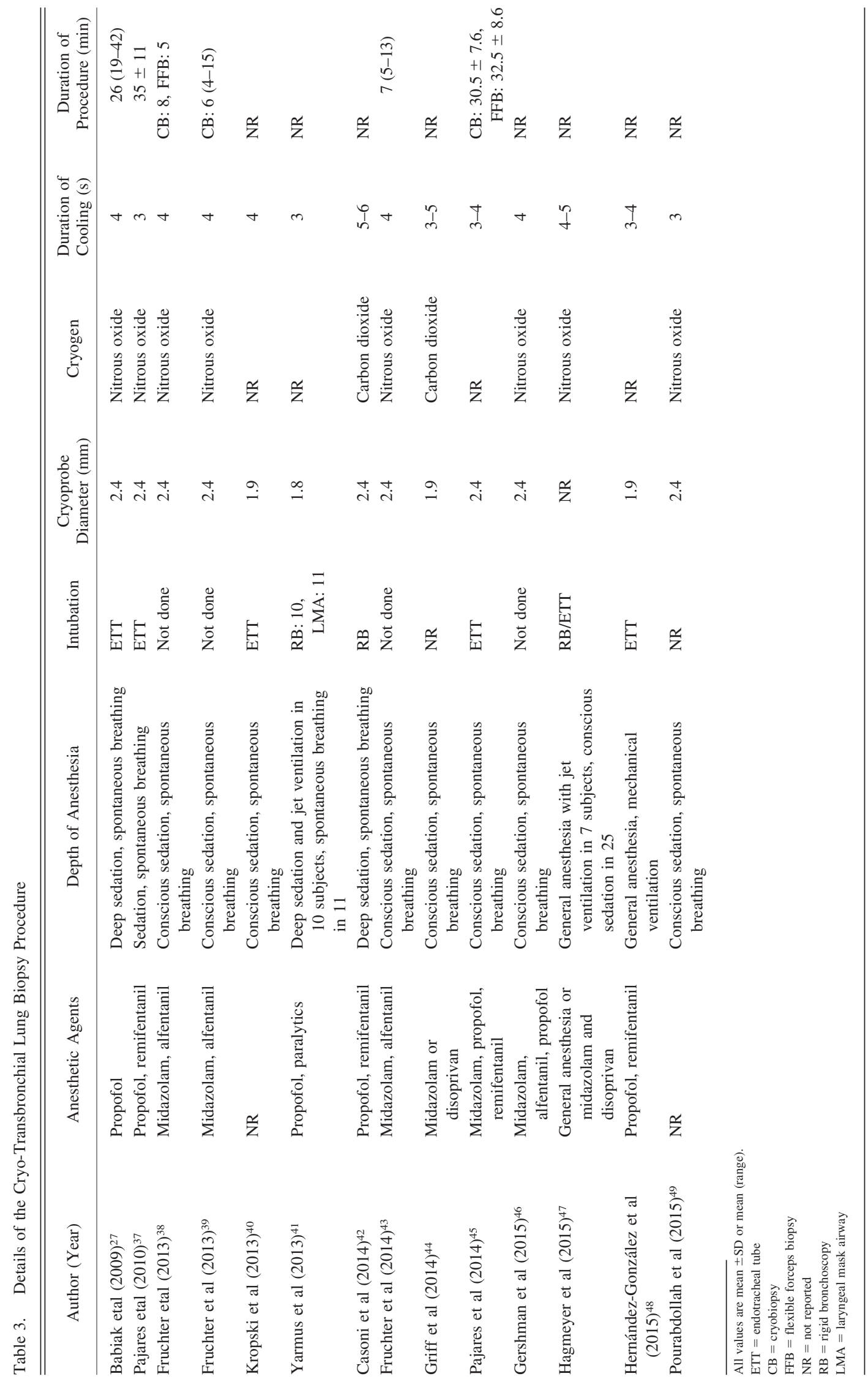


Cryoprobe Transbronchial Lung Biopsy in Diffuse Lung Diseases

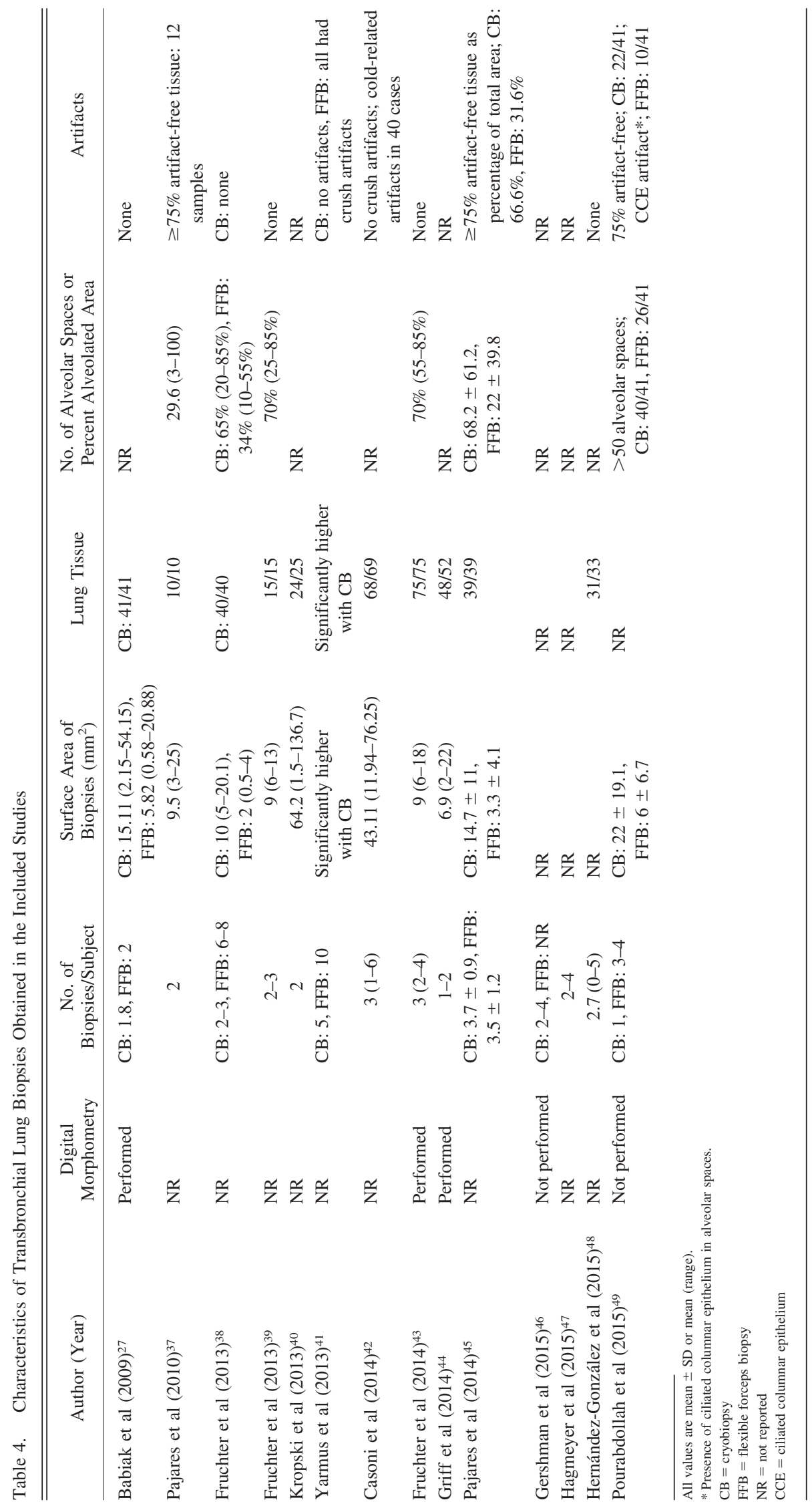




\section{Cryoprobe Transbronchial Lung Biopsy in Diffuse Lung Diseases}

Table 5. Diagnostic Characteristics in the Included Studies

\begin{tabular}{|c|c|c|c|}
\hline Author (Year) & Diagnostic Accepted Standard & Diseases Diagnosed on Cryo-TBLB $(n)$ & Diagnostic Yield* \\
\hline Babiak et al (2009) 27 & $\begin{array}{l}\text { Clinical, radiographic, and pathological } \\
\text { findings with 6-month follow-up }\end{array}$ & $\begin{array}{l}\text { IPF (15), NSIP (10), DIP (3), PLCH (1), } \\
\text { HP (3), sarcoidosis (6), DILD (1) }\end{array}$ & CB: 39/41, FFB: $24 / 41$ \\
\hline Pajares et al $(2010)^{37}$ & NR & $\operatorname{IPF}(3), \operatorname{NSIP}(2)$ & $5 / 10$ \\
\hline Fruchter et al $(2013)^{38}$ & NR & $\begin{array}{l}\text { Acute cellular rejection (4), DAD (1), } \\
\text { pneumonitis (3), normal (32) }\end{array}$ & CB: 40/40, FFB: $37 / 40$ \\
\hline Fruchter et al $(2013)^{39}$ & $\begin{array}{l}\text { Clinical, radiographic, and pathological } \\
\text { findings }\end{array}$ & $\begin{array}{l}\text { Fibrotic NSIP (1), DAD (3), OP (3), } \\
\text { noncaseating GI-2, drug-induced acute } \\
\text { interstitial pneumonitis (5), } \\
\text { cryptococcal pneumonia (1) }\end{array}$ & $12 / 15$ \\
\hline Kropski et al (2013) $)^{40}$ & $\begin{array}{l}\text { Clinical, radiographic, and pathological } \\
\text { findings }\end{array}$ & $\begin{array}{l}\text { UIP/IPF (7), COP (2), RBILD/DIP (2), } \\
\text { HP (1), malignancy (2), drug-induced } \\
(2), \text { ConB (1), BO (1), normal (1) }\end{array}$ & $20 / 25$ \\
\hline Yarmus et al $(2013)^{41}$ & None & NR & NR \\
\hline Casoni et al $(2014)^{42}$ & NR & $\begin{array}{l}\text { UIP (47), NSIP (9; } 6 \text { fibrosing, } 3 \\
\text { cellular), DIP/RBILD (2), OP (1), EP } \\
\text { (1), DAD (1), HP (1), FB (1) }\end{array}$ & $\begin{array}{l}\text { Definite: } 52 / 69 \text {, } \\
\text { definite/probable: } \\
63 / 69\end{array}$ \\
\hline Fruchter et al $(2014)^{43}$ & $\begin{array}{l}\text { Interdisciplinary discussion-clinical, } \\
\text { pathologic, radiologic }\end{array}$ & $\begin{array}{l}\text { UIP (7), NSIP (22), COP (11), PLCH } \\
\text { (3), LAM (1), DIP (1), HP (1), EP } \\
\text { (1), LC (1), sarcoidosis (1), lipoid } \\
\text { pneumonia (1), PAP (1), silicosis (1) }\end{array}$ & $\begin{array}{l}\text { Definite: } 52 / 75 \\
\text { definite/probable: } \\
73 / 75\end{array}$ \\
\hline Griff et al $(2014)^{44}$ & $\begin{array}{l}\text { Interdisciplinary discussion: clinical, } \\
\text { pathologic, radiologic }\end{array}$ & $\begin{array}{l}\text { IPF (9), NSIP (1), COP (8), HP (6), } \\
\text { DILD (2), rheumatoid lung disease } \\
\text { (2), sarcoidosis (10), alveolar } \\
\text { microlithiasis (1), pulmonary } \\
\text { manifestation of scleroderma (1), } \\
\text { histiocytosis (1) }\end{array}$ & $41 / 52$ \\
\hline Pajares et al $(2014)^{45}$ & $\begin{array}{l}\text { Interdisciplinary discussion-clinical, } \\
\text { pathologic, radiologic }\end{array}$ & $\begin{array}{l}\text { UIP (7), NSIP (12), DAD (1), OP (3), } \\
\text { HP (3), bronchiolitis-associated DILD } \\
\text { (2), sarcoidosis (1) }\end{array}$ & CB: 29/39, FFB: $13 / 38$ \\
\hline Gershman et al $(2015)^{46}$ & NR & NR & NR \\
\hline Hagmeyer et al $(2015)^{47}$ & $\begin{array}{l}\text { Interdisciplinary discussion-clinical, } \\
\text { pathologic, radiologic }\end{array}$ & $\begin{array}{l}\text { IIP (14/20), non-IIP or excluded ILD } \\
\quad(11 / 12)\end{array}$ & $\begin{array}{l}\text { Definite: } 25 / 32 \text {, } \\
\text { definite/probable: } \\
31 / 32\end{array}$ \\
\hline $\begin{array}{l}\text { Hernández-González et al } \\
(2015)^{48}\end{array}$ & $\begin{array}{l}\text { Interdisciplinary discussion-clinical, } \\
\text { pathologic, radiologic }\end{array}$ & $\begin{array}{l}\text { UIP (7), NSIP (8), LIP (1), HP (6), } \\
\text { sarcoidosis (1), OP (1), LAM (1), } \\
\text { peribronchiolar metaplasia (1) }\end{array}$ & $\begin{array}{l}\text { Definite: } 22 / 33 \text {, } \\
\text { definite/probable: } \\
26 / 33\end{array}$ \\
\hline Pourabdollah et al $(2015)^{49}$ & $\begin{array}{l}\text { Medical history, radiographic, and } \\
\text { laboratory findings }\end{array}$ & $\begin{array}{l}\text { NSIP (2), HP (1), PCP (2), PAP (2), GI } \\
\text { (16), pulmonary hemorrhage (1), } \\
\text { PLCH (1), LC (1), adenocarcinoma } \\
\text { (1), anthracosis (1), aspiration (1), } \\
\text { capilaritis (1), intravenous drug } \\
\text { disease (1) }\end{array}$ & $\begin{array}{l}\text { CB: definite: } 21 / 41 \text {; } \\
\text { definite/probable: } \\
\text { 31/41; FFB: } 14 / 41\end{array}$ \\
\hline
\end{tabular}

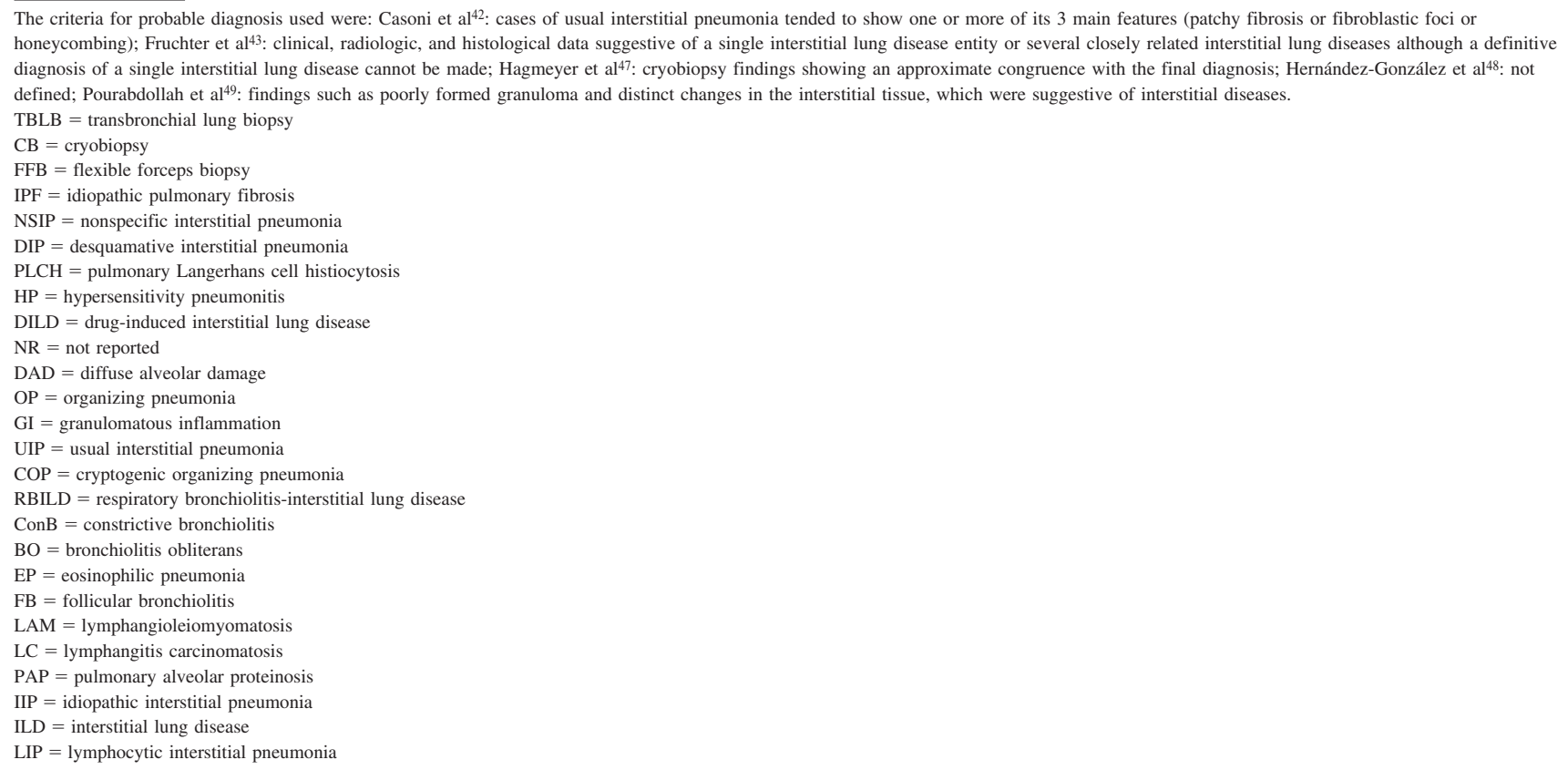




\section{Cryoprobe Transbronchial Lung Biopsy in Diffuse Lung Diseases}
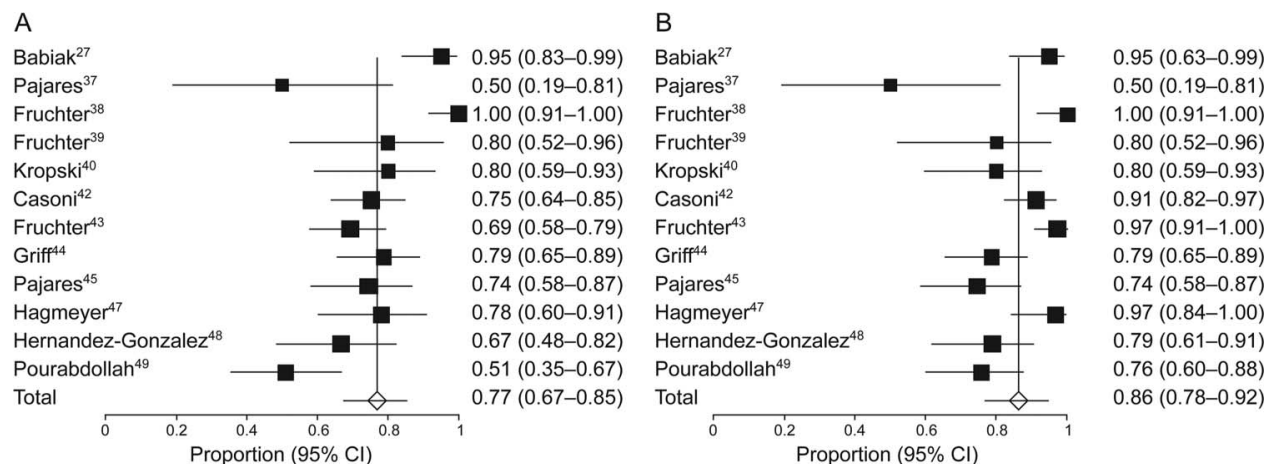

Fig. 2. Diagnostic yield of definite (A) and definite/probable (B) of transbronchial lung biopsy with cryoprobe (random effects model). The diagnostic yield in the individual studies is represented by a square (percentage) through which runs a horizontal line (95\% $\mathrm{Cl})$. The diamond at the bottom represents the pooled diagnostic yield from the studies.

Table 6. Characteristics of Studies That Compared the Diagnostic Yield of Cryoprobe Biopsy With Flexible Forceps Biopsy

\begin{tabular}{|c|c|c|c|c|c|}
\hline Author & Study Design & Diagnostic Accepted Standard & Methodology & $\begin{array}{l}\text { Actual No. of Biopsy } \\
\text { Specimens Obtained }\end{array}$ & Diagnostic Yield \\
\hline Babiak et $\mathrm{al}^{27}$ & $\begin{array}{l}\text { Retrospective } \\
\text { observational }\end{array}$ & $\begin{array}{l}\text { Clinical, radiographic, and } \\
\text { pathological findings with } \\
\text { 6-month follow-up }\end{array}$ & $\begin{array}{l}\text { FFB performed first } \\
\text { followed by CB in the } \\
\text { same subject; at least } 1 \\
\text { biopsy with each } \\
\text { technique per subject }\end{array}$ & CB: 1.8, FFB: 2 & $\begin{array}{l}\text { CB: } 39 / 41, \text { FFB: } \\
24 / 41\end{array}$ \\
\hline Fruchter et $\mathrm{al}^{39}$ & $\begin{array}{l}\text { Retrospective } \\
\text { observational }\end{array}$ & NR & $\begin{array}{l}\text { CB and FFB performed } \\
\text { in different subjects; } \\
\text { FFB group taken from } \\
\text { historical controls, 2-3 } \\
\text { biopsies with CB, 6-8 } \\
\text { biopsies with FFB }\end{array}$ & $\begin{array}{l}\text { CB: } 2(2-3), \\
\text { FFB: } 7(6-8)\end{array}$ & $\begin{array}{l}\text { CB: 40/40, FFB: } \\
\quad 37 / 40\end{array}$ \\
\hline Pajares et $\mathrm{al}^{45}$ & $\begin{array}{r}\text { Randomized } \\
\text { controlled }\end{array}$ & $\begin{array}{l}\text { Interdisciplinary discussion: } \\
\text { clinical, pathologic, } \\
\text { radiologic }\end{array}$ & $\begin{array}{l}\text { FFB and CB in different } \\
\text { subjects; at least three } \\
\text { samples taken with } \\
\text { each technique }\end{array}$ & $\begin{array}{l}\text { CB: } 3.7 \pm 0.9 \\
\text { FFB: } 3.5 \pm 1.2\end{array}$ & $\begin{array}{l}\text { CB: } 29 / 39, \text { FFB: } \\
13 / 38\end{array}$ \\
\hline Pourabdollah et al ${ }^{49}$ & $\begin{array}{l}\text { Prospective, } \\
\text { observational }\end{array}$ & $\begin{array}{l}\text { Medical history, radiographic, } \\
\text { and laboratory findings }\end{array}$ & $\begin{array}{l}\text { FFB performed first } \\
\text { followed by } \mathrm{CB} \text { in the } \\
\text { same subject; } 3-4 \\
\text { samples taken with } \\
\text { FFB, one with } \mathrm{CB}\end{array}$ & NR & $\begin{array}{l}\text { CB: definite: } 21 / 41 \text {, } \\
\text { definite/probable: } \\
\text { 31/41, FFB: } 14 / 41\end{array}$ \\
\hline \multicolumn{6}{|c|}{$\begin{array}{l}\text { All values are mean } \pm \mathrm{SD} \text { or mean (range). } \\
\mathrm{CB}=\text { cryoprobe biopsy } \\
\mathrm{FFB}=\text { flexible forceps biopsy } \\
\mathrm{NR}=\text { not reported }\end{array}$} \\
\hline
\end{tabular}

intervention for control; bleeding that led either to cardiopulmonary instability or requirement of a blood transfusion or admission to the ICU) occurred in only $0.3 \%$ of cases, similar to that seen with flexible forceps biopsy during flexible bronchoscopy, despite the significantly large size of lung tissue samples. ${ }^{7}$ It is postulated that the freezing effect of the cryoprobe coagulates the small vessels ruptured during the process of biopsy, thereby reducing the risk of significant bleeding. The data on mild and moderate bleeding are not presented because the definition of these categories was variable in the included studies. The mortality rate was also low $(0.1 \%)$, comparable with that seen with flexible forceps biopsy. ${ }^{7}$ This is much lower than that for surgical lung biopsy $(2-17 \%) .{ }^{17-23}$ It is noteworthy that all of the studies considered in this review have excluded patients who had reduced lung function, evidence of pulmonary artery hypertension on echocardiography, hemodynamic instability, hypoxemia, or coagulopathy. Thus, the findings of safety of cryo-transbronchial lung biopsy in the present analysis do not apply to patients presenting with any of these features.

The present analysis has a few limitations. First, the diagnostic reference standards used in the studies are different. In the ideal scenario, the yield of a new diagnostic 


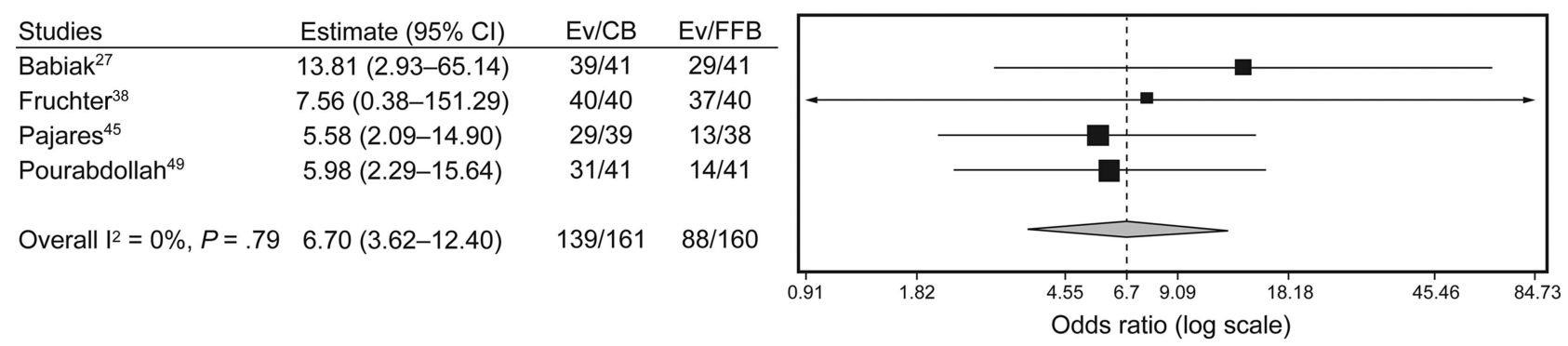

Fig. 3. Forest plot showing the diagnostic yield (both probable and definite) with transbronchial lung biopsy performed with cryoprobe (CB) versus flexible forceps biopsy (FFB). The diagnostic yield was significantly higher in the CB group (odds ratio with $95 \%$ Cls, random effects model).

Table 7. Complications Associated With Transbronchial Biopsy Reported in the Included Studies

\begin{tabular}{|c|c|c|c|}
\hline Author (Year) & Severe Bleeding & Pneumothorax & Death \\
\hline Babiak et al (2009) ${ }^{27}$ & 0 & 2 (due to FFB or $\mathrm{CB}$ ) & 0 \\
\hline Pajares et al $(2010)^{37}$ & 0 & 0 & 0 \\
\hline Fruchter et al $(2013)^{38}$ & 0 & CB: 0 , FFB: 1 & 0 \\
\hline Fruchter et al $(2013)^{39}$ & 0 & 0 & 0 \\
\hline Kropski et al (2013) $)^{40}$ & 0 & 0 & 0 \\
\hline Yarmus et al $(2013)^{41}$ & 0 & 1 (due to FFB or $\mathrm{CB}$ ) & 0 \\
\hline Casoni et al (2014) ${ }^{42}$ & 0 & 19 & 1 \\
\hline Fruchter et al $(2014)^{43}$ & 0 & 2 & 0 \\
\hline Griff et al (2014) $)^{44}$ & 0 & 0 & 0 \\
\hline Pajares et al $(2014)^{45}$ & 0 & CB: 3 , FFB: 2 & 0 \\
\hline Gershman et al $(2015)^{46}$ & 0 & CB: 15 , FFB: 9 & 0 \\
\hline Hagmeyer et al $(2015)^{47}$ & 2 & $\begin{array}{c}\text { 6/32 (jet ventilation: } 3 / 7 \text { spontaneous } \\
\text { breathing: } 3 / 25 \text { ) }\end{array}$ & 2 (SLB group) \\
\hline Hernandez-Gonzalez et al $(2015)^{48}$ & 0 & 4 & 0 \\
\hline Pourabdollah et al $(2015)^{49}$ & NR & NR & NR \\
\hline $\begin{array}{l}\mathrm{FFB}=\text { flexible forceps biopsy } \\
\mathrm{CB}=\text { cryobiopsy } \\
\text { SLB = surgical lung biopsy } \\
\mathrm{NR}=\text { not reported }\end{array}$ & & & \\
\hline
\end{tabular}

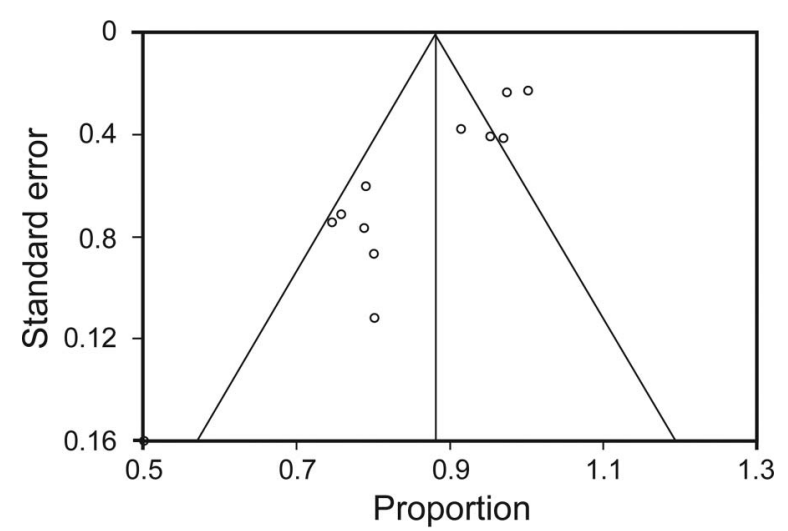

Fig. 4. Funnel plot comparing the proportion versus the SE of the proportion for the diagnostic yield. The circles represent the studies included in the meta-analysis. The line in the center indicates the summary proportion. The other lines represent the 95\% Cls. There was evidence of publication bias. modality such as cryo-transbronchial lung biopsy should be assessed using surgical lung biopsy as the reference standard, with both of the procedures performed in all of the patients. However, because surgical lung biopsy is invasive and is associated with high morbidity and mortality, many patients frequently do not consent for the performance of surgery; hence, it may not be feasible to have such a study design. A diagnosis achieved after a multidisciplinary discussion assimilating all of the clinical, radiologic, and histopathological data (also used in many of the included studies) constitutes the most feasible composite reference standard, endorsed by the American Thoracic Society/European Respiratory Society guidelines for diagnosis of idiopathic interstitial pneumonias. ${ }^{2,16}$ Also, we attributed pneumothorax as a complication to cryotransbronchial lung biopsy where both cryo-transbronchial lung biopsy and flexible forceps biopsy were performed in the same subject. However, these occurred in only 3 in- 


\section{Cryoprobe Transbronchial Lung Biopsy in Diffuse Lung Diseases}

stances, and we attributed them to cryo-transbronchial lung biopsy based on a worst case scenario analysis. Most of the studies in this analysis are retrospective observational studies, thus providing only moderate quality evidence for the utility of this technique. Finally, the studies included in this analysis have significant clinical heterogeneity because they have been performed in varied patient populations. There was also the presence of publication bias, which could impact the conclusions of the study. Hence, the results of the present analysis should be considered as hypothesis-generating and require confirmation in larger multi-center randomized trials.

\section{Conclusions}

Transbronchial lung biopsy performed with a cryoprobe during flexible bronchoscopy is safe and offers a high diagnostic yield in subjects with diseases diffusely involving the lung parenchyma. In this early appraisal, the technique seems promising in the evaluation of diffuse parenchymal lung diseases.

\section{REFERENCES}

1. Deconinck B, Verschakelen J, Coolen J, Verbeken E, Verleden G, Wuyts W. Diagnostic workup for diffuse parenchymal lung disease: schematic flowchart, literature review, and pitfalls. Lung 2013;191(1): 19-25.

2. Maher TM. A clinical approach to diffuse parenchymal lung disease. Immunol Allergy Clin North Am 2012;32(4):453-472.

3. Park CH, Paik HC, Haam SJ, Lim BJ, Byun MK, Shin JA, et al. HRCT features of acute rejection in patients with bilateral lung transplantation: the usefulness of lesion distribution. Transplant Proc 2014; 46(5):1511-1516.

4. Gasparetto EL, Ono SE, Escuissato D, Marchiori E, Roldan L, Marques HL, Frare e Silva RL. Cytomegalovirus pneumonia after bone marrow transplantation: high resolution CT findings. Br J Radiol 2004;77(921):724-727.

5. Levin DC, Wicks AB, Ellis JH Jr. Transbronchial lung biopsy via the fiberoptic bronchoscope. Am Rev Respir Dis 1974;110(1):4-12.

6. Ensminger SA, Prakash UB. Is bronchoscopic lung biopsy helpful in the management of patients with diffuse lung disease? Eur Respir J 2006;28(6):1081-1084.

7. Du Rand IA, Blaikley J, Booton R, Chaudhuri N, Gupta V, Khalid $\mathrm{S}$, et al. British Thoracic Society guideline for diagnostic flexible bronchoscopy in adults: accredited by NICE. Thorax 2013;68(Suppl 1):i1-i44.

8. Poletti V, Patelli M, Poggi S, Bertanti T, Spiga L, Ferracini R. Transbronchial lung biopsy and bronchoalveolar lavage in diagnosis of diffuse infiltrative lung diseases. Respiration 1988;54(Suppl 1): 66-72.

9. Berbescu EA, Katzenstein AL, Snow JL, Zisman DA. Transbronchial biopsy in usual interstitial pneumonia. Chest 2006;129(5):11261131.

10. Tomassetti S, Cavazza A, Colby TV, Ryu JH, Nanni O, Scarpi E, et al. Transbronchial biopsy is useful in predicting UIP pattern. Respir Res 2012;13:96.

11. Fraire AE, Cooper SP, Greenberg SD, Rowland LP, Langston C. Transbronchial lung biopsy. Histopathologic and morphometric assessment of diagnostic utility. Chest 1992;102(3):748-752.
12. Kendall DM, Gal AA. Interpretation of tissue artifacts in transbronchial lung biopsy specimens. Ann Diagn Pathol 2003;7(1):20-24.

13. Raghu G, Collard HR, Egan JJ, Martinez FJ, Behr J, Brown KK, et al. An official ATS/ERS/JRS/ALAT statement: idiopathic pulmonary fibrosis: evidence-based guidelines for diagnosis and management. Am J Respir Crit Care Med 2011;183(6):788-824.

14. Izbicki G, Shitrit D, Yarmolovsky A, Bendayan D, Miller G, Fink G, et al. Is routine chest radiography after transbronchial biopsy necessary?: A prospective study of 350 cases. Chest 2006;129(6):15611564.

15. Kumar S, Agarwal R, Aggarwal AN, Gupta D, Jindal SK. Role of ultrasonography in the diagnosis and management of pneumothorax following transbronchial lung biopsy. J Bronchology Interv Pulmonol 2015;22(1):14-19.

16. Travis WD, Costabel U, Hansell DM, King TE Jr., Lynch DA, Nicholson AG, et al. An official American Thoracic Society/European Respiratory Society statement: update of the international multidisciplinary classification of the idiopathic interstitial pneumonias. Am J Respir Crit Care Med 2013;188(6):733-748.

17. Utz JP, Ryu JH, Douglas WW, Hartman TE, Tazelaar HD, Myers JL, et al. High short-term mortality following lung biopsy for usual interstitial pneumonia. Eur Respir J 2001;17(2):175-179.

18. Kreider ME, Hansen-Flaschen J, Ahmad NN, Rossman MD, Kaiser LR, Kucharczuk JC, Shrager JB. Complications of video-assisted thoracoscopic lung biopsy in patients with interstitial lung disease. Ann Thorac Surg 2007;83(3):1140-1144.

19. Kondoh Y, Taniguchi H, Kitaichi M, Yokoi T, Johkoh T, Oishi T, et al. Acute exacerbation of interstitial pneumonia following surgical lung biopsy. Respir Med 2006;100(10):1753-1759.

20. Park JH, Kim DK, Kim DS, Koh Y, Lee SD, Kim WS, et al. Mortality and risk factors for surgical lung biopsy in patients with idiopathic interstitial pneumonia. Eur J Cardiothorac Surg 2007;31(6): 1115-1119.

21. Rena O, Casadio C, Leo F, Giobbe R, Cianci R, Baldi S, et al. Videothoracoscopic lung biopsy in the diagnosis of interstitial lung disease. Eur J Cardiothorac Surg 1999;16(6):624-627.

22. Plönes T, Osei-Agyemang T, Elze M, Palade E, Wagnetz D, Loop T, et al. Morbidity and mortality in patients with usual interstitial pneumonia (UIP) pattern undergoing surgery for lung biopsy. Respir Med 2013;107(4):629-632.

23. Matsuoka K, Kuroda A, Kang A, Imanishi N, Nagai S, Ueda M, Miyamoto Y. Surgical results of video-assisted thoracic surgery and risk factors for prolonged hospitalization for secondary pneumothorax in elderly patients. Ann Thorac Cardiovasc Surg 2013;19(1):1823.

24. Dhooria S, Bal A, Sehgal IS, Aggarwal AN, Behera D, Agarwal R. Transbronchial lung biopsy with a flexible cryoprobe: first case report from India. Lung India 2016;33(1):64-68.

25. Hetzel J, Eberhardt R, Herth FJ, Petermann C, Reichle G, Freitag L, et al. Cryobiopsy increases the diagnostic yield of endobronchial biopsy: a multicentre trial. Eur Respir J 2012;39(3):685-690.

26. Sehgal IS, Dhooria S, Agarwal R, Behera D. Use of a flexible cryoprobe for removal of tracheobronchial blood clots. Respir Care 2015; 60(7):e128-e131.

27. Babiak A, Hetzel J, Krishna G, Fritz P, Moeller P, Balli T, Hetzel, M. Transbronchial cryobiopsy: a new tool for lung biopsies. Respiration 2009;78(2):203-208.

28. Kmet LM, Lee RC, Cook LS. Standard quality assessment criteria for evaluating primary research papers from a variety of fields. Edmonton, Canada: Alberta Heritage Foundation for Medical Research; 2004.

29. Freeman MF, Tukey JW. Transformations Related to the Angular and the Square Root. Ann Math Stat 1950;21(4):607-611. 


\section{Cryoprobe Transbronchial Lung Biopsy in Diffuse Lung Diseases}

30. Miller JJ. The Inverse of the Freeman-Tukey Double Arcsine Transformation. Am Stat 1978;32(4):138-138.

31. DerSimonian R, Laird N. Meta-analysis in clinical trials. Control Clin Trials 1986;7(3):177-188.

32. Deeks JJ, Higgins JPT, Altman DG. Analysing and presenting results. In: Alderson P, Green S, Higgins JPT, editors. Cochrane Reviewers' Handbook 422 [updated Mar 2004]. Chichester, UK: John Wiley Sons, Ltd, 2004;68-139.

33. Fleiss JL. Analysis of data from multiclinic trials. Control Clin Trials 1986;7(4):267-275.

34. Dear K, Begg C. An approach to assessing publication bias prior to performing a meta-analysis. Stat Sci 1992;7:237-245.

35. Egger M, Davey Smith G, Schneider M, Minder C. Bias in metaanalysis detected by a simple, graphical test. BMJ 1997;315(7109): 629-634.

36. Begg CB, Mazumdar M. Operating characteristics of a rank correlation test for publication bias. Biometrics 1994;50(4):1088-1101.

37. Pajares V, Torrego A, Puzo C, Lerma E, Gil De Bernabé MA, Franquet T. [Transbronchial lung biopsy using cryoprobes]. Arch Bronconeumol 2010;46(3):111-115.

38. Fruchter O, Fridel L, Rosengarten D, Rahman NA, Kramer MR. Transbronchial cryobiopsy in immunocompromised patients with pulmonary infiltrates: a pilot study. Lung 2013;191(6):619-624.

39. Fruchter O, Fridel L, Rosengarten D, Raviv Y, Rosanov V, Kramer MR. Transbronchial cryo-biopsy in lung transplantation patients: first report. Respirology 2013;18(4):669-673.

40. Kropski JA, Pritchett JM, Mason WR, Sivarajan L, Gleaves LA, Johnson JE, et al. Bronchoscopic cryobiopsy for the diagnosis of diffuse parenchymal lung disease. PLoS One 2013;8(11):e78674.

41. Yarmus L, Akulian J, Gilbert C, Illei P, Shah P, Merlo C, et al. Cryoprobe transbronchial lung biopsy in patients after lung transplantation: a pilot safety study. Chest 2013;143(3):621-626.

42. Casoni GL, Tomassetti S, Cavazza A, Colby TV, Dubini A, Ryu JH, et al. Transbronchial lung cryobiopsy in the diagnosis of fibrotic interstitial lung diseases. PLoS One 2014;9(2):e86716.

43. Fruchter O, Fridel L, El Raouf BA, Abdel-Rahman N, Rosengarten D, Kramer MR. Histological diagnosis of interstitial lung diseases by cryo-transbronchial biopsy. Respirology 2014;19(5):683-688.

44. Griff S, Schönfeld N, Ammenwerth W, Blum TG, Grah C, Bauer TT, et al. Diagnostic yield of transbronchial cryobiopsy in non- neoplastic lung disease: a retrospective case series. BMC Pulm Med 2014;14:171

45. Pajares V, Puzo C, Castillo D, Lerma E, Montero MA, RamosBarbón D, et al. Diagnostic yield of transbronchial cryobiopsy in interstitial lung disease: a randomized trial. Respirology 2014;19(6): 900-906.

46. Gershman E, Fruchter O, Benjamin F, Nader AR, Rosengarten D, Rusanov V, et al. Safety of cryo-transbronchial biopsy in diffuse lung diseases: analysis of three hundred cases. Respiration 2015; 90(1):40-46.

47. Hagmeyer L, Theegarten D, Wohlschlager J, Treml M, Matthes S, Priegnitz C, et al. The role of transbronchial cryobiopsy and surgical lung biopsy in the diagnostic algorithm of interstitial lung disease. Clin Respir J 2015; 10.1111/crj.12261.

48. Hernández-González F, Lucena CM, Ramírez J, Sánchez M, Jimenez MJ, Xaubet A, et al. Cryobiopsy in the diagnosis of diffuse interstitial lung disease: yield and cost-effectiveness analysis. Arch Bronconeumol 2015;51(6):261-267.

49. Pourabdollah M, Shamaei M, Karimi S, Karimi M, Kiani A, Jabbari HR. Transbronchial lung biopsy: the pathologist's point of view. Clin Respir J 2015; 10.1111/crj.12207.

50. Gupta D, Dadhwal DS, Agarwal R, Gupta N, Bal A, Aggarwal AN. Endobronchial ultrasound-guided transbronchial needle aspiration vs conventional transbronchial needle aspiration in the diagnosis of sarcoidosis. Chest 2014;146(3):547-556.

51. Goyal A, Gupta D, Agarwal R, Bal A, Nijhawan R, Aggarwal AN. Value of different bronchoscopic sampling techniques in diagnosis of sarcoidosis: a prospective study of 151 patients. J Bronchology Interv Pulmonol 2014;21(3):220-226.

52. Poletti V, Cazzato S, Minicuci N, Zompatori M, Burzi M, Schiattone ML. The diagnostic value of bronchoalveolar lavage and transbronchial lung biopsy in cryptogenic organizing pneumonia. Eur Respir J 1996;9(12):2513-2516.

53. Ibrahim AS, Allangawi MH, Sattar HA, Mobyed HS, Almohammed AA. Indications, diagnostic yields and complications of transbronchial biopsy over 5 years in the State of Qatar. Saudi Med J 2005; 26(4):641-645.

54. Hue SH. Complications in transbronchial lung biopsy. Korean J Intern Med 1987;2(2):209-213. 